\title{
Survey of HAART/ART in HIV/AIDS Patients
}

\section{Rajeev R Shah ${ }^{1 *}$, Tracy William² ${ }^{2}$ Apoorwa Gupta ${ }^{3}$}

${ }^{1}$ Professor and Head, Microbiology Department, PMCH, Udaipur, India ${ }^{2}$ William Dental Clinic, Peris, France

${ }^{3}$ Apollo Hospital, Indore, India

*Corresponding Author: Rajeev R Shah, Professor and Head, Microbiology Department, PMCH, Udaipur, India.

DOI: $10.31080 /$ ASPS.2020.04.0492

\section{Background}

The Human Immunodeficiency Virus (HIV) has changed from life threatening to chronic condition due to the almost universal use and accessibility of antiretroviral treatment (ART) among HIV patients. Antiretroviral (ARV) treatment works by suppressing the viral load and restoring the immune system. Once patients start Highly Active Antiretroviral Therapy (HAART), it is to be continued lifelong in spite of its many adverse side effects. Zidovudine (AZT) a nucleoside reverse transcriptase inhibitor is the first line antiretroviral regimen in India, and was the first break through in AIDS therapy in 1990. It is known to be associated with life threatening toxicity like anaemia.

\section{Objective}

To identify the adverse drug reactions (ADRs) to antiretroviral therapy (ART) and to assess their impact on treatment compliance in patients with HIV/AIDS in western India. This study even included prevalence of AZT induced anaemia in HIV infected patients initiated on AZT containing antiretroviral therapy regimen in western India.

\section{Methods}

A retrospective study was conducted in Gujarat to study the adverse effects after HAART initiation in 1244 patients on HAART who were evaluated retrospectively for their adverse drug reactions (ADRs).This retrospective study was carried out in ART Centres, of western India (Gujarat). HIV infected patients registered at ART Centres were treated according to guideline of National AIDS Control Organization (NACO). Other 1269 patients with haemoglobin $(\mathrm{Hb})>8 \mathrm{~g} / \mathrm{dl}$ were prescribed AZT based antiretroviral therapy regimens who may even be included for previous group. Patients who developed anaemia $(<8 \mathrm{~g} / \mathrm{dl})$ due to other causes of anaemia were excluded from the study. Even attempt had been made to correlate of baseline characteristic (age, gender, starting haemoglobin level, patients weight, CD4 count and WHO clinical stages) with risk of developing anaemia.

\section{Results}

The most common first line regimen was stavudine +lamivudine+efavirenz $(\mathrm{d} 4 \mathrm{~T}+3 \mathrm{TC}+\mathrm{EFV})(68.6 \%)$ followed by stavudine + lamivudine + nevirapine $(\mathrm{d} 4 \mathrm{~T}+3 \mathrm{TC}+\mathrm{NVP})(17.9 \%)$;
Received: December 24, 2019

Published: February 01, 2020

(C) All rights are reserved by Rajeev R Shah., et al. zidovudine+ lamivudine + nevirapine (AZT+3TC+NVP) (10.9\%); and zidovudine+lamivudine+efavirenz (AZT + 3TC +EFV) 2.5\%. The first line of regimen was modified in $136(10.9 \%)$ patients, the most common cause for modifying therapy being development of an adverse effect $721(57.9 \%)$ and completion of antituberculous therapy in 510 cases(41.\%). The most common cause for modifying therapy was skin rashes due to NVP in $279(22.4 \%)$ followed by loss of appetite 195(17.2\%).One hundred eighty one (14.2\%) patients on AZT regimen developed anaemia( $<8 \mathrm{~g} / \mathrm{dl})$. Out of this 78 patients(6.15\%) developed severanaemia $(<6.5 \mathrm{~g} / \mathrm{dl})$. Females were more prone to develop anaemia. No correlation had been found between development of anaemia and age, weight, WHO clinical stage and CD4 counts. Interpretation \& conclusion: High incidence of AZT induced anaemia were found in the TB/HIV coinfections, BMI $<18 \mathrm{~kg} / \mathrm{m}^{2}$ and $\mathrm{MCV}<80 \mathrm{fL}$ in the present study. In these risk group patients regular monitoring of $\mathrm{Hb}$ should be carried out in such patients, particularly even in women on AZT based antiretroviral regimens.

\section{Conclusion}

A significant proportion of patients had adverse effects of HAART. A significant proportion of those started on NVP-based regimens are more likely to substitute therapy when compared with those on non-NVP-based regimens.

\section{Assets from publication with us}

- Prompt Acknowledgement after receiving the article

- Thorough Double blinded peer review

- Rapid Publication

- Issue of Publication Certificate

- High visibility of your Published work

Website: https://www.actascientific.com/

Submit Article: https://www.actascientific.com/submission.php Email us: editor@actascientific.com

Contact us: +919182824667 